\title{
Studies on a Korean Buddhism Community: Searching for Unity Through Open Discourse
}

\author{
Hae-Young Won \\ Dongguk University, Seoul, South Korea
}

\begin{abstract}
Korean Buddhism community has tried to develop its traditions as well as maintaining them through open discussion. Some current incidents, such as the election of the director for the headquarters of the Chogye Order, controversial issues on a prime minster nominee, and the difference between practicing and learning which has been discussed in Buddhist Academia, have generated a new wave in the Korean Buddhism world. Many religious practices which have infiltrated Korean society, including Catholicism and Christianity, have been indigenized to become a unique religious form combined with Korean Shamanism, through which individuals want to achieve personal happiness or material prosperity. Buddhism has been through the same process. Additionally, Buddhism has played a leading role in teaching the public of Korea for a long time and has become a model role for solving national crises. Currently, the Korean Buddhism world has tried to be reborn as a religion that keeps these beneficial traditions in Korea, and the Korean Buddhism can play a positive role in every aspect of culture, politics, and society. Further, the Korean Buddhism is looking for ways to influence Korean society through open discussions. This paper brings out issues that Korean Buddhism faces and presents the solutions to solve those problems.
\end{abstract}

Keywords: the Chogye Order, Korean Buddhism, Korean society, practice, Buddhist Academia

\section{Introduction}

Today, Korean Buddhism faces a new challenge. Korean society has reacted sensitively not only toward a person's political ideology but also her religious beliefs. This social atmosphere ostensibly seems to divide the religious world but actually unites it, especially the Buddhism world in South Korea. Korean Buddhism has shown a movement to reform the Buddhism community through self-criticism and self-examination of the current issues of Korean Buddhism. This movement is not a simple, transient reaction to the current issues that Korean society faces, but is based on basic Buddhism philosophical ideas which have contributed to leading Korean society since the early Buddhism, when the religion entered Korea.

This world we live in is not perfect and the people who live in this imperfect and unstable world cannot escape from the suffering innate to the human mind. There is nothing immortal in the living organism anywhere in this world, because the world and humans are like a drop of water in the river (諸行無常, 一切皆苦, 諸法 無我). This idea is a unique Buddhist creed, which is different from other religious ideas.

If one believes that a principle or truth exists separately and that principle or truth controls the world, including humans, that humans can escape from the suffering, depending on the existence, and that there

Hae-Young Won, Researcher, Department of Buddhism, Dongguk University. 
is an existential self that someday will reach the pāramitā, she might have to choose something other than Buddhism. Buddhism criticizes the ideas that there is a metaphysical existence or an absolute god. However, Buddhism does not advocate agnosticism or nihilism because humans enter the world where they experience suffering from the moment they are born. Buddhism teaches that humans can find "a middle path" (中道, majjhimāpatipadā). This path can liberate humans from something that human mind is involved in, such as suffering and pleasure (苦樂), being and no-being (有無), and vanity or eternity. In other words, this condition is called “no-self” (無我), “no-self nature”(無自性), or “emptiness”(空). If one acquires a discrimination wisdom (分別智) that transcends the sensible knowledge or judgment, he or she reaches the level of "total wisdom". However, it is not easy for humans who are part of the world of senses to transition from that world.

In this sense, the act of renunciation that occurs upon entrance of the new promising space after achieving the middle path causes one to realize emptiness, leaving the secular world, which is an illusion of inevitability, and selecting reasoning as a major activity for a new start. According to Hannah Arendt, Samgha is the space time where a group of free men with initiative tries a new start and builds a boundary and where they have face-to-face discussion and live together. Strictly speaking, human histories consist of a network of human relationships wherever it may be (Arendt, 2005, p. 232; Arendt, 1996, p. 242). The early Buddhist community, which consisted of key Buddhist laymen, kept its identity pure by making its issues public and by solving the problems with opinions of monks from outside the community.

The current system and atmosphere of Korean Buddhism community has become similar to those of the early Buddhism community. Each issue is exposed to the world and goes public, and its solutions are discussed. The conflicts stemming from political ideas surface as easily as those of political issues. In this situation, the mass media and Buddhism communities play a more important role in asking for solutions rather than political power. This paper examines how much of a ripple effect that the religious beliefs of government officials has on certain issues in South Korea, and it will also deal with how much of an effort Buddhism communities make to narrow the gap between the Buddhist scholars and laymen. These discussions are important to predict the characteristics and future of Korean Buddhism communities.

\section{The Election of the Director for the Headquarters of the Chogye Order and the Nomination of High Ranking Government Officials}

In this section, this paper explores the Buddhist democracy that scholars from different disciplines have discussed, not from a Buddhist textbook. In "Karl Jaspers: Citizen of World?" Arendt mentioned the axis of world history that penetrated the 5th century BC. Humans found the human condition on earth at this time. The development of a great civilization was started at this time of this axis (Arendt, 1994, pp. 134-138). Both Polis and Samgha were born in the center of this axis and passed down.

The democratic election of the early Buddhism is based on traditional Samgha. The reason that the election of the director for the Headquarters of the Chogye Order in Korea must be in accordance with the traditional way of an election is that the traditional way is based on a democratic foundation, freedom. Traditionally, the Buddhism world executes “direct democracy” (大衆公事) and has a decision making process which is based on the full concordance of the members (Jo, 2006, p. 38). Currently, the Korean Buddhism world has adopted an indirect election to select the director for the Headquarters of the Chogye Order; this process cannot reflect the opinions of the public (Geumgang, 2005, pp. 106-107). 
On October 5, 2013, the weekly global magazine, The Economist exposed the corruption of Korea's Chogye Order in an article titled "Korean Buddhism Monkey Business". The magazine criticized Korean Buddhism, stating "The biggest Buddhism Order does not mean graceful and intellectual one". It is a pity that the Korean Chogye Order was mocked by the world famous news magazine (England Economist, 2013). Since the true Buddhist practices are not found easily even in the Buddhism world recently and a few incidents that did not follow the teachings of Buddha also occurred, Buddhism scholars tried to find out the gap between Buddhism itself and Buddhism studies. In Korean the distrust in Buddhist monks from laymen came to the surface.

In addition, the Buddhist community has agreements with the religious opinions of the government officials. This paper focuses on the columns that were written after the recent prime minister nominee's voluntary resignation.

Professor Hong Seonggi criticized the Korean Broadcasting System (KBS) on distortions from sound bites of MunChanggeuk, the prime minister nominee saying "the situation resembles [a witch hunt], which Hitler's fascism used" when he came to power after overthrowing the German Weimar Republic. Hong pointed out that the reports of KBS and other media outlets on Mun were unfair and amplified the conflicts caused by the ideological differences between liberals and conservatives.

This process is not unfamiliar to Koreans. At first, the press reports a certain story in a biased way. Then, the political parties accept it and use it as a weapon to attack the opposite party. Afterwards, the news spreads out through social networks (SNS), Internet new outlets, and traditional presses. Then, the intellectuals, citizen groups, social groups, and some religious groups which recognize the political meaning of the issue join the controversial debate.

This process gets faster because of the Internet, a cutting edge technology in South Korea. This short-cycled feedback repeats very quickly, and the whole society becomes involved in this social issue. Eventually, this social phenomenon causes a "whirlwind of the falsity", which is group madness. As a result, when a big conflict that causes political and economic impact occurs, the political parties or the ruling government gives into the pressure of the group madness. Here, the distortion of the facts is caused by a few reporters and TV producers but the result caused by them hits Korean society hard. Regardless of the justification of the report, the output caused by a singular, small input has a big impact. A distorted report often generates public hatred toward certain individuals, certain groups, or an administration. The hatred toward an individual or a group makes it impossible to have empathy toward the subject of the hatred, regardless of political ideology, ethnic group, or religion, because it is impossible to have both hatred and empathy simultaneously toward a group.

As a result, hatred prohibits individuals from feeling empathy; although they know others unfairly suffer from difficulties mentally, socially, physically, or even in a worse case, encourages them to participate in the violent act. Surely, the blind love makes the opposite situation. However, there is no subjective difference between "fair anger" based on facts and "biased report" based on the distortions of the facts. To distinguish between the two, dispassionate, objective, and reasonable judgment based on facts is needed. Otherwise, the biased anger is misjudged as fair anger by the public, which eventually will make the society. In fact, distorting facts prohibits real recognition of facts. Therefore, prohibiting certain information and distorting facts are a basic method to justify a dictatorship and to keep a regime's safety by distorting anger toward the outer world, like in North Korea. 
Information screening can be generated in an open society like South Korea by certain groups who have different ideological or religious logics voluntarily. Therefore, "fair anger" can be one of the most important factors for a revolution that tears down a dictatorship. Meanwhile, the group madness caused by distorted anger can play a key role in over throwing a democratic system by distorting a decision making process, creating a social disorder. The group madness caused by distorted facts is not a psychopathological phenomenon but a socio-pathological one, such as bullying, group hatred, and group violence.

But, there is a similarity between the two phenomena. In a situation where individuals have a fight about what is true, an individual or a group under the control of irrational logic like madness shows a tendency to display strong tolerance which does not respond from truth. For example, a morbid suspicion of a wife's chastity or delusion of chastity toward a husband that are considered to be a delusion in psychopathology, which cannot be healed by any logical persuasion or counter-evidence, because they dismiss the proof or information which prove their suspicion voluntarily, considering them as ad hoc subsidiary supposition. This is applied to the socio-pathological group madness where the tolerance for resisting the truth is stronger.

Because of this reason, the discussion to find the truth becomes a fight between two political sides - liberal and conservative. The privilege of exemption is endowed to a press that delivers a distorted truth, political parties, citizen groups, and intellectuals that join in the spreading of the distorted truth, because they are conspirators.

When some reporters are sued on a charge of defamation of character or when there is a conflict between a press union and its employers, international organizations, such as "Reporters Without Borders" or "Freedom House", reduces the marks of the democratization realization index or free press and criticize the oppression of the press.

Other solutions to fix distorted facts are asking the Press Arbitration Commission to order the press to redress the damages or the Korea Communications Standards Commission to punish the press or the reporter who provided distorted facts. However, these solutions are not that effective of a measure to prevent such distorted reports. Also, both sides of the political parties do not accept the slightest restrain or blame that as a political oppression. In particular, it is theoretically impossible to limit the kind of distorted reports, because that kind of reporting is executed under the name of freedom of the press, which is the key idea of the democracy.

Therefore, without a strong sense of responsibility from the press, there is no effective measure to prevent the distortion of the fact in South Korea. Now, it has become common and safe for the press as a group to distort facts and disperse them, which eventually instigates the public without any restraint. That means the media came to achieve a way by which they can carry out violence. Here, threatening democracy is not an illegal type of violence, but legal, which is done under the name of freedom of speech and ideas(Hong, 2014).

The Korean Buddhism world expressed its opinion about the Mun Prime Minister Nominee as it united its opinion. They expressed a rather sensitive concern toward the religious ideas of the government officials who can have strong influence to affect the opinion of the public as officials show concerns about corruption. Then, what does a religion mean in South Korea?

\section{The Meaning of Buddhism in South Korea}

The education of religion, which has the goals of examining and improving the lives of individuals and the promotion of the coexistence of all of the members of society, enriches the moral culture of a society. It can 
help alleviate contentious factors in a community. However, although the volume of religious education has increased, the exclusive acts toward a different religion has been done even in the public sector and the little endeavors to contribute to a public good or to fix the ideological polarization of a society have been done. That is, the current religious education in South Korea cannot influence in order to change the world view or form the life of an individual.

Why is it important that Buddhists know what Christianity is? What is the communication and understanding between the different religions for? What kinds of attitudes exist toward different religions? If Buddhists and Christians, who occupy the half of the Korean population, have kept an indifferent relationship with each other and have their own monologue, it will be unfortunate for Korean society and undesirable to improve harmony and peace of Korea. A cooperative relationship between the two religions in South Korea will enrich the religious life of the public and will provide stability and prosperity of the whole Korean society.

The census issued in 2005 shows index that the Buddhism world has to pay attention to. Comparing the one of 1995, the population of Buddhists in 2005 was reduced by $0.4 \%$, from $23.2 \%$ to $22.8 \%$, and Christians, from $19.7 \%$ to $18.3 \%$. Meanwhile, Catholics increased from $6.6 \%$ to $10.9 \%$ (see Figure 1).

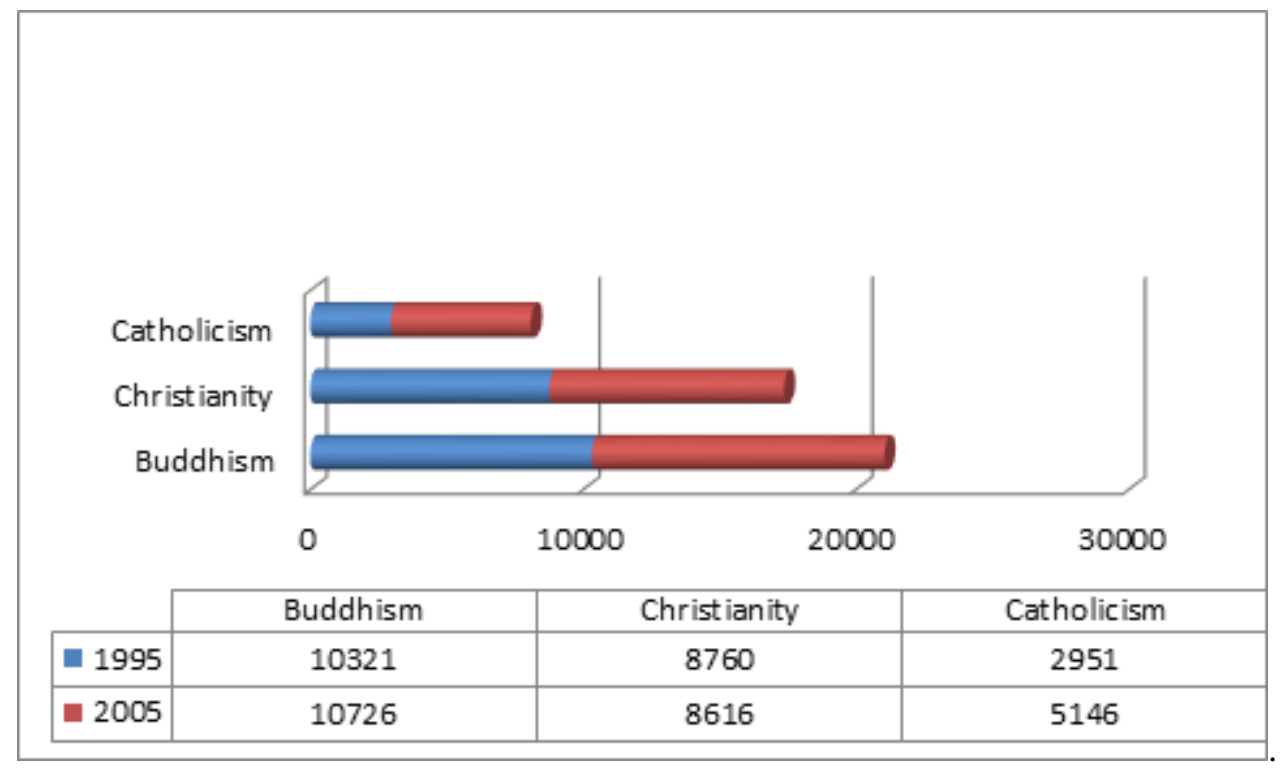

Figure 1. Religious population change year, 2005 Census.

Regardless of the religion, the Korean people who take to the teachings of Buddha as life lessons started to increase since the 1980s and keep increasing until recently. Korea has been under the direct influence of Buddhism. Along with Confucianism, Buddhism has become ingrained in Korean society as a tradition. Catholicism in South Korea came to resemble Buddhism in terms of becoming a part of the Korean people's lives. As a result, the Catholic population grows.

Buddhism saw Śăkyamuni Buddha as "philosopher" of India, born in the era of axis, and also as an archetype of "a Victorian gentleman" who has a balanced mind (Cho, 2012, pp. 54-55; Philip, 1988). These opinions elevated the status of Buddhism as a study positively. However, on the other hand, it is a negative aspect when Buddhism has wanted to solely focus on its practices and religious beliefs.

The question has often been asked: Is Buddhism a religion or a philosophy? It does not matter what you call it. Buddhism remains what it is regardless of whatever label you may put on it. The label is immaterial. 
Even the label "Buddhism", which we give to the teaching of the Buddha, is of little importance. The truth needs no label the truth is not Buddhist, Christian, Hindu, nor Moslem. No entity holds a monopoly on the truth. Sectarian labels are a hindrance to the independent understanding of the truth, and they produce harmful prejudices in the minds of people. This is true not only in intellectual and spiritual matters, but also in human relations (Walpola, 1959, p. 5).

Big ideas from ethics, ontology, epistemology, metaphysics, moral psychology, phenomenology, and neurology are united around the naturalization of Buddhism. Buddhism has an integral tendency as a study. Buddhism is a practical philosophy that has specific practical contents called "skillful means" that help one to understand the meaning of life. However, metaphysical, mysterious, and pure religious factors are excluded from Buddhism.

People can live following the teachings of Buddha, although they do not believe in Buddhism as religion. Therefore, some Buddhist scholars argue that there is a difference between Buddhism and Buddhism studies. Buddhism does not consider meditation simply as a skill or a method for mental exercise; it provides philosophical and naturalized foundation. "Temple Stay", which is a representative program through which people can experience the lifestyle of Buddhist monks in South Korea, is called "National Healing Camp". However, if that program does not provide a chance to reflect the life of the participants, only focusing on mechanical procedures of a temple life, even the volunteer activities and sacrificed lives of bodhisattva can be misunderstood.

\section{Is the History of Buddhism History of Buddhism Studies?}

How is the gap between Buddhism itself and the studies on Buddhism in South Korea filled and unified? Perfect unity cannot be expected. As mentioned before, when social or religious controversial issues surface, Buddhist monks and laymen express their different opinions. It is true that the clear difference among the groups reveal the clear community identity. Whenever open and critical opinions come out, Buddhists become disappointed. This is the primary foundation which shows the difference between Buddhism as a religion and Buddhism Studies. When Buddhism Studies is strictly focusing on logic, Buddhism is more flexible. This binary division can be rather controversial among scholars, but it is worth mentioning it, considering there is a gap between the practice of and the studies in Korean Buddhism.

Some Buddhist scholars in South Korea argue that practice or meditation is not helpful to understand the Buddhism text, emphasizing that distinguishes Buddhism from Buddhism studies. Ohmin Kwan asks, "What is Buddhist practice?" and "How does Buddhism studies influence its practice?" Kwan argues that there are few common factors between Buddhism and Buddhism studies. He criticizes that Buddhism studies is treated as poor imitation of Buddhism. He points out that it is not right to only focus on the practice of Buddhism and to think that the practice of Buddhism is everything when considering Buddhism as a whole(Kwan, 2009, p. 115).

Kwan expressed his opinion on applied Buddhism, which was fully accepted by Korean Buddhism world recently. He mentioned, "I cannot agree with the opinion that applied Buddhism is an area of Buddhism studies or its modernized version. Although, I admit the necessity of applied Buddhism, and it is a Buddhist scholar's responsibility to provide ideas or logics necessary to Buddhism Ecology or Sociology" (Kwan, 2007). He continued and said, "Buddhism studies must criticize the present through the previous Buddha teachings and predict the future. Understanding the issues presented without critical investigation is not based on Buddhism studies but on dogma". 
Seongtak Jo mentions related to this matter as follows: "Since the modern Buddhism introduced, Buddhism studies in Korea created various Buddhist discourses that focus on doctrines and practice system for 100 years. Also, it presents Buddhist point of views to various fields, such as environment, ecology, feminism, social participation, meditation, and ontology. However, some Buddhist remarks do not provide a realistic effectiveness and do not communicate with other humanistic perspectives remaining a monologue trapped in the Buddhism World. This is because the traditional understanding of Buddhist doctrines is applied to the modern context without a revision to the reality. This is also because there is no process of reinterpreting Buddhism doctrines and discourses. "To make Buddhist teaching be realized in the actual lives, a reinterpretation of the traditional teachings in the modern context is needed" (Cho, 2014).

My argument on this matter is that meditation and practice are not the same, but the public expects the same effect from them. Think about why the contemporary world gets into the meditation, which originated from the ancient times. The modern society suffers from mental, physical, or psychological disorders like a disease. Among them, stress-related diseases are believed to be treated by meditation because of the psychological effect according to brain science.

The goal of Buddhism studies is primarily to satisfy interest and suspicion but ultimately to present the new ideas that fit the contemporary times. To do that, it is necessary to understand the Buddhism studies of the past and the critical research on Buddhism literature. If Buddhist scholars only talk about the theoretical teaching written in the textbooks, what is said is not true scholarship.

Since Buddhism is not a "casual result of everyday life" but "results from experience", it cannot be a common speculation. The reason that Buddhism is explained with experientialism or rationalism can be found in the modern context. However, it is not fair to say that Buddhism cannot enhance an ability to recognize daily life. Many metaphors written in Buddhist canon are related to how to understand everyday life. That understanding can be said to be a final project, but it is a logical jump to say it cannot build a way of thinking in everyday living related to enlightenment or reasoning.

Not all the Buddhist scholars in Korea agree on the opinion that practice is not related to Buddhism studies. Some scholars have begun to understand there is a difference between practice and Buddhism studies. This trend tends to lead the change in Korean Buddhism. They try to rebuild the status of Buddhism studies as an independent academic area by emphasizing on basic ideas and the world views of Buddhism.

Considering the current situation of Korean society, it is difficult to judge whether this trend will be a new environment for Buddhism studies and will provide a new direction and energy to Buddhist scholars or whether it will lead to decline Buddhism studies despite the quantitative growth.

\section{How to Reduce the Gap Between Practice and Academic Studies of Korean Buddhism}

Inside the world of Buddhism, there is a different opinion between Buddhist monks and laymen about Buddhism studies and Buddhism. This difference may come from the difference among "scholars and scholar monks", "colleges and Buddhist temples", and "everyday world and nirvana world". (Cho, 2014). Korean Buddhism may have to choose what its priority is: practice or scholastic research. According to an early Buddhism text, "religious practices consist of two factors: One is virtuous acts that bring happiness to the world, and the other is mind training that brings success". (Bhadanta, 1965, p. 285). For the purpose of religious practice, Buddhism has to choose both acts to bring happiness to the world and its devotees.

If the virtue of the Buddhism as a religion is emphasized, the importance of practice will not be ignored. In 
fact, at first, practice was to study it as a scholarship. It is believed that training the mind changes the brain. Meditation training, which has been passed down for thousands of years, has a great power to heal an individual's live and make it healthy. This argument has been proven by neuroscience. The system theory of Gary Schwartz explains the healing mechanism of meditation. The psychological mechanism of healing is that meditation makes an individual understand the individuality of a thing in the context of totality. The reasons for psychological problems that are prevalent today are that partiality or individuality is emphasized too much, so the connection between an individual and the whole is fragmented. According to this system theory, all living things functions through a co-adjustment between a low ranking of the system and a high ranking of the system. So, when there is a disconnection between the low ranking and high ranking, problems occur. When emotional oppression causes problems of self-attention, an individual cannot recognize the various processes happening inside of her. This lack of self-attention, which is called "disattention", generates a disconnection between body and mind. This disconnection causes "disregulation", which makes a disorder. That disorder finally makes individuals sick. Seen from the perspective of healing, meditation that makes individuals recognize a change in the mind and body makes a disconnection become connected. Then, this connection makes disregulation be regulated; the regulation gives the disorder order. The order forces the nervousness to ease, and finally healing occurs (Schwartz, 1989). The scientific proof of a practice like meditation is owed to Buddhism studies.

On the other hand, it is a responsibility of Buddhism to prevent the one-sidedness of practice. Spiritual enlightenment is a type of practice that Korean Buddhism mostly employs; Korean Buddhism firmly adheres to the principle that Zen Buddhism is the true teaching of Buddha. Buddhism scholars have to make an effort to get out of these biased thoughts. The religious environment that has changed in the modern Korean society does not allow for this religious bias. In the past, the practice to acquire the enlightenment was believed to belong to Buddhism monks, but currently, many Buddhist scholars are interested in practice. The scholars who discuss the gap between Buddhism and Buddhism studies prove the change.

It is an illusion to believe that the practice for enlightenment that was born in the religious and social environment of China and Zen Buddhism, whose goal was to acquire "the ultimate knowledge", emphasizing practice can be maintained as the original form in the modern society where a new religious environment occurs. The Buddhist scripture describes practice as a "mysterious tradition" that belongs to only Buddhism monks. In the past, the laymen could have Buddha teaching only through the words of the Buddhist monks to live ethically by doing pious acts was everything they practiced.

However, the desire of the current Korean Buddhists has very different aspects. They read Buddhist Scripture by themselves and try to practice Buddha's teaching in their lives. Almost all traditional Buddhism books as well as the Mahayana Sutras were translated and introduced to Korea. The religious authority that Buddhist monks enjoyed through teaching the scripture and the authority of the Mahayana Sutras itself are not the same as before in South Korea.

The reason that we want to examine the early form of Buddhism is in the same vein of this trend. Early Buddhism defines the Buddhist community as a group of Buddhist priests, Buddhist nuns, Buddhist laymen, and Buddhist laywomen. The early scripture emphasizes that the harmony and consideration of the community members. It is a mistake to consider that this community was isolated from a society, only to practice in solitude. At that time, Buddhist monks mainly practiced, and this way of living is a characteristic of the Buddhist communication. The harmony of disciplinants is an important factor in maintaining the Buddhist community (Won, 2009, pp. 412-413). Also, Buddhist scripture plays a central role in harmonizing the 
community. The harmony of Buddhism itself and Buddhist studies should be achieved like that of the early Buddhism era. The reason we of examine the early Buddhism is not just to follow the doctrine of that time but to find a model that can follow and find truth.

It is certain that practice has benefits for individuals. So what do Buddhist scholars have to do to achieve an academic advantage through practice? As mentioned earlier, some Buddhist scholars think that academic studies and practices are two different things. Then, are practice and life separated? I do not think so. Are practice and academic studies separated? They might be. Can the gap between practice and academic studies be filled? I think it is possible as I mention earlier.

Change from belief to practice has complex aspects. It is not a natural process to change from belief to practice. After listening to Buddha's teaching, some decided to stay at where they were to practice his teaching, and some left the mundane world to become monks to practice. Therefore, even if some have belief, their starting point of practice is not the same. Practice has an exclusive starting point (Akira, 2001, p. 188). A lot of effort and interest are needed to change belief to practice and practice to academic strictness.

Keep in mind that truth cannot be acquired solely through belief and practice. Did early Buddhism emphasize only practice and belief? It emphasized academic doubt for the proper transmission of the Buddhist truth. It is important that Buddhism studies the Buddhism texts with objective view points. Buddhism teaches one to balance two sides, which became its unique characteristic. Buddhism is supported by belief and practice, and Buddhism embraces rational and logical Buddhist philosophy and Buddhism studies. Now, Korean Buddhism has been discussing how practice and academic studies can narrow the gap and communicate with each other.

\section{Conclusion}

Buddhism has never stayed where it stood, keeping its tradition while building a new tradition to adapt itself to the new religious environment, which keeps changing. And, it tries to realize the original message from Buddha. Now is the time that Korean Buddhism has to change, as it faces the more drastic changes of the times. The modern history tells us that if you follow the change of the time, you and your groups can meet a crisis. The current Korean Buddhism has some kind of this crisis, because Korean Buddhism has not realized Buddhism itself as the truth properly or created distrust, and it failed to adapt to the new religious environment.

However, open discussion and conversation started to change Korean Buddhism and pushed it to have democracy of the early Buddhism era. Currently, Korean Buddhism is interested in how mental problems and suffering can be healed by experience. Also, it shows interests in objective and logical issues in addition to historical and philosophical issues. Korean Buddhism tries to communicate between Buddhism and Buddhism Studies.

\section{Refesrences}

Akira, H. (2001). Studies on original Buddhism. Tokyo: Shunjusha Publishing Company.

Arendt, H. (1996). Human conditions. Seoul: Hangilsa.

Arendt, H. (2005). Between the Past and the Future. Seo, Yukyung, Pureunsup.

Arendt, H., \& Canovan, M. (1994). Hannah Arendt: A reinterpretation of her political thought. Cambridge: Cambridge University Press.

Cho, S. (2012). Buddhism and Buddhism Studies. Stone Pillow.

Cho, S. (2014). Buddhism religion, Buddhism and Buddhist studies: At the interchange of pre-modern and post-modern. Horizon of Knowledge, No. 16. 
England (英) Economist. (2013). Korean Buddhism, Monkey Business.

Geumgang. (2005). Religion and election. Seoul: Modern Buddhism Newspaper.

Hong, S. (2014). KBS distortion of facts, group madness instigates the group violence. Ajou University.

Jo, G. (2006). Religious affairs administration. Seoul: Dongguk University Press.

Kwan, O. (2007). Mecca of world Buddhism studies. Beopbo Newspapers (p. 886).

Kwan, O. (2009). Buddhism studies and buddhism. Seoul: Minjoksa.

Philip, C. A. (1988). The British discovery of Buddhism. Cambridge: Cambridge University Press.

Saddhatissa, H. (1965). Upāsakajanālañkāra-A critical edition and study. Pali Text Society, Luzac.

Schwartz, G. E. (1989). Disregulation theory \& psychosomatic disease: A system approach. In S. Cheren (Ed.), Psychosomatic medicine: Theory, research and practice. New York: International University Press.

Walpola, R. (1959). What the Buddha taught. New York: Grove Press.

Won, H. (2009). Buddha's Nirvana Episode of beautiful community. Kyeongseowan. 